\title{
ГІГІЄНІЧНЕ ОБГРУНТУВАННЯ ВДОСКОНАЛЕННЯ КРИТЕРІЇВ ВІДБОРУ ДЛЯ ПРОВЕДЕННЯ МОНІТОРИНГУ ХІМІЧНИХ РЕЧОВИН, ЩО МОЖУТЬ ВПЛИВАТИ НА ФУНКЦІОНУВАННЯ ЩИТОПОДІБНОЇ ЗАЛОЗИ (НА ПРИКЛАДІ ПЕСТИЦИДІВ)
}

\section{Антоненко А. М., Вавірневич О. П.}

\section{ВСТУП}

Як відомо, серед усіх факторів, що впливають на стан здоров'я населення, чинники навколишнього середовища становлять 20\%. Але, враховуючи сучасний рівень денатурації біосфери, негативний вплив іiі забруднення стає все більш відчутним. Захист і зміцнення здоров'я населення можна забезпечити, 3 одного боку, заходами захисту навколишнього середовища, а 3 іншого, за допомогою контролю його стану (моніторингу). Своєю чергою в структурі негативних факторів навколишнього середовища чи не найбільша питома вага належить хімічним речовинам ${ }^{1}$.

Останніми роками виявлення й моніторинг забруднення довкілля у Сполучених Штатах Америки проводиться за допомогою підходів, що стосуються біосистем. Для цього використовуються кілька груп рослин, тварин і мікроорганізмів. Агенція з охорони навколишнього середовища (ЕРА) розглядає біомоніторинг як корисний пристрій для моніторингу забруднення навколишнього середовища 3 точки зору діагностичних, профілактичних і корективних заходів ${ }^{2}$.

За даними Європейської економічної комісії Організації Об'єднаних Націй UNECE (далі - ЄEK OOH) за останнє десятиліття лише деякі країни Свропи та Центральної Азії змогли підтримувати моніторингові діï $^{3}$. У багатьох містах субрегіону моніторинг забруднення атмосферного повітря поганий. Моніторинг твердих і небезпечних відходів $\epsilon$ слабким, а виробничі викиди також недостатньо контролюються, що знижує ефективність таких інструментів політики, як витрати на викиди й штрафи. Моніторинг транскордонного забруднення повітря

${ }^{1}$ Pradyot Patnaik. Handbook of Environmental Analysis: Chemical Pollutants in Air, Water, Soil, and Solid Wastes, Third Edition. Tailor and Francis Group, New York, 2018. 628 p.

EPA Monitoring Programs. URL: https://www.epa.gov/measurementsmodeling/monitoring-programs.

${ }^{3}$ UNECE AND UNFPA. "UNECE monitoring framework for the icpd programme of action beyond 2014”. UNECE and UNFPA, Geneva and Istanbul, 2018. 
також потребує посилення. Крім того, багатьом європейським i центральноазіатським країнам бракує єдиних національних методологій у різних галузях моніторингу, а їхні класифікаційні системи часто несумісні з міжнародними стандартами.

На П'ятій конференції з питань довкілля для Європи (Київ, 2003 р. $)^{4}$ Міністри СЕК OOH (UNECE) схвалили рекомендації щодо посилення екологічного моніторингу й інформаційних систем у країнах Свропи та Центральної Азії, підготовлені Робочою групою ЄЕК ООН 3 моніторингу навколишнього середовища.

Відомо також, що одним із провідних факторів ризику негативного впливу антропогенних чинників на стан здоров'я населення й працівників є застосування пестицидів, особливо тих, які використовують 3 великими нормами витрат ${ }^{5}$. Відомо, що неконтрольоване використання пестицидів для захисту сільськогосподарських культур може призвести до порушень стану здоров'я працівників і споживачів ${ }^{6}$. Саме тому ми обрали пестициди як показові хімічні сполуки для розроблення нашої методики.

Моделі моніторингу довкілля, які є на сьогодні, передбачають проведення спостережень за станом навколишнього природного середовища (повітря, вод суші, прибережних вод, грунтів), рівнем його забруднення. Однак у них не закладено специфічні критерії для моніторингу хімічних сполук, які впливають на щитоподібну залозу, що $є$ надзвичайно актуальним для багатьох країн світу ${ }^{7}$.

Саме тому метою нашої роботи було гігієнічне обгрунтування критеріїв відбору для проведення моніторингу й оцінки ризику впливу на здоров'я людини хімічних речовин, що можуть впливати на щитоподібну залозу (на прикладі пестицидів).

\section{1. Гігієнічне обгрунтування критеріїв відбору для проведення моніторингу пестицидів,} що впливають на функціонування щитоподібної залози

У 2017 році О. П. Вавріневич зі співавторами було розроблено й обгрунтовано механізм удосконалення та розроблено схему

4 Fifth Ministerial Conference “Environment for Europe”. URL: http://www.unece.org/fileadmin//DAM/env/efe/Kiev/proceedings/welcome.html.

${ }^{5}$ Acute occupational pesticide-related illness and injury - United States, 2007-2011. The National Institute for Occupational Safety and Health (NIOSH) / G. M. Calvert et al. URL: https://www2a.cdc.gov/nioshtic-2/BuildQyr.asp.

6 Occupational exposure to pesticides and the incidence of lung cancer in the agricultural health study. The National Institute for Occupational Safety and Health (NIOSH) / M. R. Bonner et al. URL: https://www2a.cdc.gov/nioshtic-2/BuildQyr.as.

State of the Scientific of Endocrine Disrupting chemicals - 2012. URL: http://www.who.int/ceh/publications/endocrine/en/. 
функціонування системи державного соціально-гігієнічного моніторингу фунгіцидів в об'єктах навколишнього середовища ${ }^{8}$.

Автори пропонували використовувати критерії, які враховували:

1) регіональне пестицидне навантаження $(>0,3$ кг/га);

2) фізико-хімічні властивості (тиск пари $>1 \times 10^{-4}$ мПа, розчинність У воді, > 100 мг/л; коефіцієнт сорбції в грунті $\left(K_{\text {ос }}\right)<75$ / > 500);

3) токсикологічну небезпечність (клас небезпечності 1-2; величина допустимої добової дози < 0,01 мг/кг; коефіцієнт можливості інгаляційного отруєння (КМІО) > 2,0; коефіцієнт вибіркової дії (КВД) < 99 ; професійний ризик $>1)$;

4) стійкість в об'єктах довкілля й екотоксикологічну небезпечність (період напівруйнування $\left(\tau_{50}\right)$ у грунті $>30$ діб; індекс персистентності пестицидів (ІПП) > 20; екотоксикологічну небезпеку (Екотокс) $>0,4 ; \tau_{95}$ у воді > 10 діб; індекс потенційного вимивання (GUS) $>1,8 ; \tau_{50}$ у сільськогосподарській сировині > 14 діб).

Нашою ж метою було вдосконалення запропонованої раніше моделі й доповнення іiі новими специфічними критеріями відбору для проведення моніторингу хімічних речовин (на прикладі пестицидів), що можуть впливати на щитоподібну залозу.

На сьогодні $\epsilon$ багато факторів навколишнього середовища, що негативно впливають на щитоподібну залозу за різними механізмами дії. Пестициди в списку таких факторів посідають одне з провідних місць. Хоча слід зазначити, що більшість із них не впливають на щитоподібну залозу безпосередньо й на синтез нею гормонів, а в більшості випадків індукують метаболізм і виведення тиреоїдних гормонів.

Результати проведеної нами токсиколого-гігієнічної оцінки й вивчення механізмів дії пестицидів ${ }^{9,10}$ дали змогу виділити, крім раніше обгрунтованих токсикологічних критеріїв відбору для проведення моніторингу (класу небезпечності й величини допустимої добової дози), ще два специфічних показники: вплив на щитоподібну залозу як орган-мішень i вираженість тирозинемії, індукованої пестицидом (рівень тирозину в плазмі крові, нмоль/мл).

За результатами багаторічних досліджень i розрахунків установлено, що в грунтово-кліматичних умовах центральної та

8 Вавріневич О. П. Гігієнічне обгрунтування критеріїв відбору для проведення моніторингу в агропромисловому комплексі України. Довкілля $i$ здоров'я. 2019. № 1. С. 4-9. doi.org/10.32402/dovkil2019.01.004.

${ }_{9}$ Mechanism of action of 4-hydroxyphenylpyruvate dioxygenase inhibitor herbicide on homoterm animals and humans / A. M. Antonenko et al. Journal of Pre-Clinical and Clinical Research. 2015. Vol. 9. № 2. P. 148-153.

10 Антоненко А. М., Коршун М. М., Мілохов Д. С. Особливості механізму дії інгібіторів сукцинатдегідрогенази на організм теплокровних тварин та людини. Сучасні проблеми токсикології, харчової та хімічної безпеки. 2015. № 4 (72). С. 23-29. 
південної Європи (на прикладі умов України) ризик забруднення грунтових вод сучасними найпоширенішими фунгіцидами (наприклад, ізопіразамом, пентіопірадом, седаксаном, флуксапіроксадом) i більшістю гербіцидів (наприклад, ацетохлором, диметахлором, пропизохлором, S-метолахлором, тієнкарбазон-метилом, ізоксафлютолом, мезотріоном, гліфосатом) низький, а максимально можливі їхні концентрації в грунтових водах незначні й набагато нижчі за допустимі, що пов'язано 3 низькими нормами витрат гербіцидів i незначним відсотком діючих речовин у формуляціях фунгіцидів i свідчить про відносну безпечність для здоров'я людини при вживанні води, в яку могли потрапити досліджувані сполуки ${ }^{11,12}$. На основі отриманих даних було запропоновано додатковий критерій оцінки небезпечності для об'єктів навколишнього середовища для системи моніторингу пестицидів - індекс потенційного забруднення грунтових i поверхневих вод (далі - LEACH) ${ }^{13}$.

LEACH, на нашу думку, $\epsilon$ найбільш оптимальним індексом потенційного вимивання. На відміну від широко використовуваного показника GUS (Ground Ubiquity Score), який не враховує всі значущі параметри, що можуть впливати на поведінку пестициду в системі «Грунт - вода», запропонований показник визначає можливість забруднення не лише грунтових вод, але й річок, куди пестициди можуть вимиватися з поверхневим стоком; він враховує максимальну кількість параметрів, що можуть впливати на перехід пестицидів із грунту в інші середовища.

Для оцінки небезпеки для здоров'я людини при вживанні контамінованих шкідливими хімічними речовинами (в тому числі й пестицидами) води та харчових продуктів (так звані непрофесійні контингенти або bystanders, а також професійні контингенти в неробочий час) у світі є декілька методик оцінки ризику ${ }^{14,15,16}$. Усі вони грунтуються

${ }^{11}$ Prediction of soil and ground water contamination with fungicides of different classes according to soil and climate conditions in Ukraine and other European countries / O. P. Vavrinevych et al. Georgian Medical News. 2015. № 5 (242). C. 73-84.

${ }^{12}$ Comparative hygienic risk assessment of groundwater contamination by herbicides of different chemical classes and hazard prediction for human after consumption of contaminated water / A. M. Antonenko et al. Journal of Education, Health and Sport. Poland. 2016. № 9. P. 873-882.

${ }^{13}$ Claudia A. Spadotto Screening method for assessing pesticide leaching potential. Pesticidas : R. Ecotoxicol. Curitiba. 2002. Vol. 12. P. 69-78.

${ }^{14}$ European Food Safety Authority. Exposure to pesticides data for residents and bystanders, and for environmental risk assessment. URL: https://data.europa.eu/ euodp/data/dataset/exposure-to-pesticides-data-for-residents-and-bystanders-and-forenvironmental-risk-assessment. 
переважно на простому порівнянні величин можливого споживання пестициду з продуктом (MRL (maximum residue level, або максимальний рівень залишків) $\times$ максимальне або середнє по регіону споживання продукту) та його допустимого добового надходження (ADI).

Однак жодна 3 цих моделей не $є$ досконалою й не враховує всі можливості й умови споживання питної води чи харчових продуктів, контамінованих небезпечними хімічними сполуками. Тому нами було запропоновано алгоритми оцінювання ризику для здоров'я людини в разі потрапляння пестицидів різними шляхами в ії організм у повсякденному житті (непрофесійний контакт з пестицидами) (рис. 1 і рис. 2).

Запропонований алгоритм оцінювання небезпечності для людини під час вживанні контамінованої небезпечними хімічними речовинами (на прикладі пестицидів) води ${ }^{17}$ полягає у бальній оцінці таких чинників:

1) показника можливості міграції (LEACH) у поверхневі й підземні води, що можуть бути джерелами господарсько-питного водопостачання. Ризик потрапляння речовин у водойми є завжди, але необхідно оцінити його величину, яка буде залежати від фізико-хімічних властивостей сполуки в першу чергу; меншою мірою - від умов навколишнього середовища;

2) періоду напівруйнування сполуки у воді. Яка б кількість речовини не потрапила у водний резервуар, важливо, як довго вона там може зберігатися для реалізації можливості споживання такої води людиною;

3) допустимої добової дози, від якої залежить можливість реалізації токсичних ефектів за постійного надходження хімічних речовин в організм людини.

Після додавання всіх присвоєних балів за кожен критерій отримуємо інтегральний показник небезпечності за вживання контамінованої води (далі - IПНВВ), який оцінюється таким чином: 3 i 4 бали - речовини малонебезпечні для людини (4 клас), 5 і 6 - помірно небезпечні (3 клас), 7 і 8 - небезпечні (2 клас), 9 і 10 високонебезпечні (1Б клас), 11 і 12 - надзвичайно небезпечні (1А клас).

${ }^{15}$ GUIDANCE OF EFSA: Guidance on the assessment of exposure of operators, workers, residents and bystanders in risk assessment for plant protection products. European Food Safety Authority (EFSA) Journal. 2014. № 12 (10). P. 3874-3924.

${ }_{16}$ Report of the Joint working group on bystander risk assessment (BRAWG). Advisory Committee on Pesticides Committee on Toxicity of Chemicals in Food, Consumer Products and the Environment, US EPA. 2013. 70 p.

17 Prediction of pesticide risks to human health by drinking water extracted from underground sources / A. M. Antonenko et al. Georgian Medical News. 2015. № 7-8 (244-245). P. 99-106. 


\begin{tabular}{|c|c|c|c|c|}
\hline \multicolumn{5}{|c|}{ Показники } \\
\hline \multicolumn{3}{|c|}{$\begin{array}{l}L E A C H_{\text {mod. }}=\frac{S_{w} \times \tau_{50 \text { field }}}{K_{\text {ос }}}, \text { де } \\
\mathrm{S}_{\mathrm{w}}-\text { розчинність у воді, мг/л; } \\
\tau_{50 \text { field }- \text { період напівруйнування речовини в }} \\
\text { грунті в натурних умовах, доба; } \\
\mathrm{K}_{\text {ос }}-\text { коефіцієнт сорбції органічним вуглецем, } \\
\text { мл/г о.в. }\end{array}$} & $\begin{array}{l}\tau \quad 50 \quad \mathrm{y} \\
\text { воді, } \\
\text { діб }\end{array}$ & $\begin{array}{l}\text { Допустима } \\
\text { добова доза } \\
\text { (ДДД), мг/кг }\end{array}$ \\
\hline \multicolumn{5}{|c|}{ Присвосння балів залежно від значення показника } \\
\hline Бали & LEACH & $\tau_{50}$ & & ДДД \\
\hline 1 & $<0,01$ & $<5$ & & $>0,02$ \\
\hline 2 & $0,01-0,1$ & $5-10$ & & $0051-0,02$ \\
\hline 3 & $0,11-1,0$ & $11-30$ & & $0021-0,005$ \\
\hline 4 & $>1,0$ & $>30$ & & $\leq 0,002$ \\
\hline \multicolumn{5}{|c|}{$\downarrow$} \\
\hline \multicolumn{5}{|c|}{$\begin{array}{c}\text { Інтегральний показник небезпечності за потрапляння у воду } \\
\text { ІПНВВ }=\mathrm{LEACH}+\tau_{50}+\text { ДДД (балів) } \\
\end{array}$} \\
\hline \multicolumn{5}{|c|}{$\downarrow$} \\
\hline \multicolumn{5}{|c|}{ Оцінка ІПНВВ і встановлення класу небезпечності } \\
\hline 3 і 4 бали & \multicolumn{4}{|c|}{ речовини мало небезпечні для людини (4 клас) } \\
\hline 5 і 6 балів & \multicolumn{4}{|c|}{ помірно небезпечні (3 клас) } \\
\hline 7 і 8 балів & \multicolumn{4}{|c|}{ небезпечні (2 клас) } \\
\hline 9 і 10 балів & \multicolumn{4}{|c|}{ високо небезпечні (1Б клас) } \\
\hline 11 і 12 балів & \multicolumn{4}{|c|}{ надзвичайно небезпечні (1А клас) } \\
\hline
\end{tabular}

Рис. 1. Схема оцінки та прогнозування небезпеки в разі потрапляння пестицидів в організм людини 3 водою ${ }^{18}$

Також запропоновано алгоритм оцінки небезпечності для людини за вживання контамінованих небезпечними хімічними речовинами (на прикладі пестицидів) харчових продуктів ${ }^{19}$, який полягає у бальній оцінці:

${ }^{18}$ Спосіб прогнозування негативного впливу на здоров'я населення пестицидів при їх потраплянні в організм 3 водою : патент на корисну модель 105428; заявл. 03.07.2015; опубл. 25.03.2016, Бюл. № 6.4 c.

19 Гігієнічне обгрунтування моделі прогнозування небезпеки для людини при вживанні сільськогосподарських продуктів контамінованих пестицидами (на прикладі фунгіцидів класу піразолкарбоксамідів) / А. М. Антоненко та ін. The unity of science. Vienna, Austria. August 2018. P. 46-48. 


\section{Показники}

Середнє споживання продукту (C), г/добу (Якщо продукт вживають в сирому вигляді або використовують як дитяче харчування, для бальної оцінки період напівруйнування збільшують вдвічі; для дітей до 18 років вводиться додатковий коефіиієнт запасу (КЗ)

\begin{tabular}{|c|c|c|c|}
\hline \multicolumn{3}{|c|}{ Присвосння балів залежно від значення показника } \\
\hline Бали & С & $\tau_{50}$ & ДДД \\
\hline 1 & $<100$ & $<5$ & $>0,02$ \\
\hline 2 & $100-200$ & $5-14$ & $0,0051-0,02$ \\
\hline 3 & $201-300$ & $15-30$ & $0,0021-0,005$ \\
\hline 4 & $>300$ & $>30$ & $\leq 0,002$ \\
\hline \multicolumn{4}{|c|}{ Інтегральний показник небезпечності під час вживання продуктів } \\
\hline \multicolumn{4}{|c|}{ ІПНВХП = С $+\tau_{50}+$ ДДД (балів) } \\
\hline \multicolumn{4}{|c|}{ Оцінка ІПнВХП і встановлення класу небезпечності } \\
\hline 3 і 4 бали & речовини малонебезпечні для людини (4 клас) \\
\hline 5 і 6 балів & помірно небезпечні (3 клас) \\
\hline 7 і 8 балів & небезпечні (2 клас) \\
\hline 9 і 10 балів & високонебезпечні (1Б клас) \\
\hline 11 і 12 балів & надзвичайно небезпечні (1А клас) \\
\hline
\end{tabular}

Рис. 2. Схема оцінювання ризику й прогнозування небезпеки в разі потрапляння пестицидів в організм людини 3 харчовими продуктами ${ }^{20}$

1) середнього споживання продукту в г/добу, що буде визначати можливість надходження певного продукту в організм людини взагалі та його орієнтовну кількість. Має відмінності в різних країнах і навіть регіонах однієї країни. Можна використовувати офіційні нормативні документи та рекомендації або експериментально (опитування, менюрозкладка, ваговий або інші методи оцінки харчування). При оцінці середньодобового споживання продуктів для дітей від 1 до 18 років цей показник множать на коефіцієнт запасу, який розраховують шляхом

${ }^{20}$ Гігіснічне обгрунтування моделі прогнозування небезпеки для людини при вживанні сільськогосподарських продуктів контамінованих пестицидами (на прикладі фунгіцидів класу піразолкарбоксамідів). Інформаційний лист на нововведення у сфері охорони здоров'я. Міністерство охорони здоров'я України, Український центр наукової медичної інформації та патентно-ліцензійної роботи. Вип. 1 «Гігієна харчування». 2018. № 28.5 с. 
поділу середньої маси тіла дорослої людини (непрофесійні контингенти) 60 кг (М) на середню масу тіла дитини певного віку $\left(\mathrm{M}^{21}:\right.$ КЗ $=\mathrm{M} / \mathrm{M}$. Таким чином, коефіцієнт запасу для дітей до 1 року становить 6,0 ; для дітей від 1 до 5 років - 3,0; 6-10 років - 2,0; 11-14 років - 1,5; 15-18 років - 1,2. Якщо досліджуваний пестицид застосовують на різних сільськогосподарських культурах, величини їхнього середньодобового споживання додаються й оцінюється в балах сумарне середньодобове споживання;

2) періоду напівруйнування сполуки в рослині. Яка кількість речовини не потрапила б на/в рослину, важливо, як довго вона там може зберігатись і наскільки вона є стійкою до різних видів оброблення. Якщо препарати на основі досліджуваної сполуки застосовують на різних культурах або в різних грунтово-кліматичних умовах, то для оцінювання беруть найбільше значення періоду напівруйнування;

3) і аналогічно попередньому алгоритму - допустимої добової дози, від якої залежить можливість реалізації токсичних ефектів у разі постійного надходження хімічних речовин в організм людини.

Після додавання всіх присвоєних відповідних показникам балів інтегральний показник небезпечності в разі вживання контамінованих харчових продуктів (далі - ІПНВХП) оцінюють таким чином: за величини 3-5 балів - речовини малонебезпечні для людини (4 клас), 6-8 - помірно небезпечні (3 клас), 9-11 - небезпечні (2 клас), 11-12 - надзвичайно небезпечні (1 клас).

Таким чином, нами було запропоновано додаткову групу критеріїв для проведення моніторингових досліджень - показники небезпечності в разі потрапляння в організм людини (інтегральний показник небезпечності за вживання контамінованої води (ІПНВВ) й інтегральний показник небезпечності в разі вживання контамінованих продуктів (ІПНВХП)).

Проведений аналіз токсичності, механізмів дії, ризику для навколишнього середовища й організму людини досліджуваних пестицидів, що впливають на щитоподібну залозу, дав змогу обгрунтувати схему функціонування системи моніторингу небезпечних хімічних речовин (на прикладі пестицидів), які можуть негативно впливати на функціонування щитоподібної залози 22.

Під час вирішення питання про необхідність проведення моніторингу пестициду або іншої небезпечної хімічної сполуки, що впливає на щитоподібну залозу, оцінюють кожен із запропонованих критеріїв у балах (табл. 1) і знаходять їхню загальну суму.

${ }^{21}$ WHO child growth standards : length/height-for-age, weight-for-age, weight-forlength, weight-forheight and body mass index-for-age: methods and development. World Health Organization. France. 2006. 336 p.

${ }^{22}$ Improvement of the monitoring system in the environment of pesticides affecting thyroid gland / A. M. Antonenko et al. Довкілля i здоров'я. 2019. № 4 (93). С. 12-18. 


\begin{tabular}{|c|c|c|c|c|c|c|c|}
\hline & 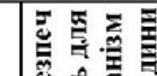 & игеg 'ШХянШ & \begin{tabular}{|c|} 
\\
\\
$v^{\prime}$
\end{tabular} & $\begin{array}{l}0 \\
\text { in }\end{array}$ & 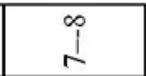 & $\stackrel{a}{A 1}$ & 氞总总 \\
\hline & 总卷 응 & иเеg 'ЯЯНाI & \begin{tabular}{|c|} 
\\
$\mathrm{V}^{\prime}$
\end{tabular} & in & $\stackrel{\infty}{n}$ & $\begin{array}{l}0 \\
\mathrm{Al}\end{array}$ & 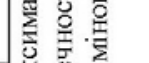 \\
\hline 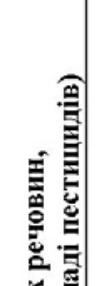 & 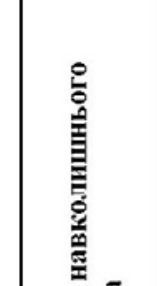 & $\begin{array}{c}\text { г/.59w } \\
\text { 'MO४S-IOS }\end{array}$ & $\left|\begin{array}{c}0 \\
\hdashline \\
x \\
0 \\
\hdashline \\
v\end{array}\right|$ & $\begin{array}{c}0 \\
0 \\
x \\
0 \\
0 \\
1 \\
1 \\
0 \\
0 \\
x \\
0 \\
-\end{array}$ & $\begin{array}{l}\overrightarrow{0} \\
\frac{0}{x} \\
0 \\
i \\
1 \\
30 \\
\frac{0}{x} \\
= \\
=\end{array}$ & $\begin{array}{l}\frac{1}{0} \\
x \\
0 \\
1\end{array}$ & 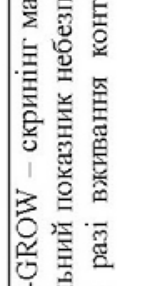 \\
\hline 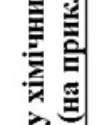 & 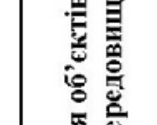 & ${ }^{\circ} \mathrm{c} \boldsymbol{\kappa}$ 'HวVН' & $\mid \begin{array}{l}3 \\
0 \\
0 \\
v\end{array}$ & $\overrightarrow{\hat{\theta}}$ & $\frac{0}{1}$ & $\stackrel{\circ}{i}$ & 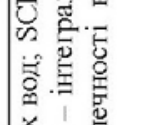 \\
\hline 를 & 帛 & $\frac{\text { egor }}{\text { 'xвниц'эod } S^{0 \mathrm{~s}_{1}}}$ & $\because$ & $\frac{ \pm}{n}$ & $\begin{array}{l}\circ \\
1 \\
n\end{array}$ & $\stackrel{\text { }}{\wedge}$ & 离㘣邑 \\
\hline 훌 월: & 胥 & goor '!̣tog $K{ }^{0 \varsigma_{2}}$ & 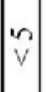 & $\stackrel{9}{1}$ & $\stackrel{\circ}{1}$ & $\stackrel{\circ}{\wedge}$ & 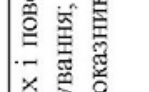 \\
\hline 可题 & 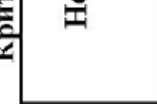 & 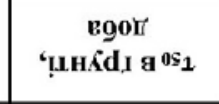 & $\bar{v}$ & @ & $\frac{8}{\frac{1}{m}}$ & $\frac{\mathrm{I}}{\mathrm{A}}$ & 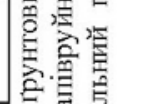 \\
\hline 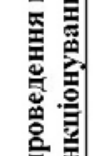 & & 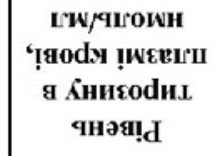 & $\begin{array}{c}8 \\
\mathrm{~m} \\
\mathrm{v}\end{array}$ & $\frac{\substack{8 \\
\frac{1}{8}}}{8}$ & $\begin{array}{l}8 \\
\frac{1}{1} \\
\frac{8}{8}\end{array}$ & $\frac{8}{8}$ & 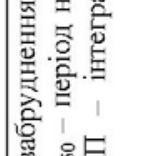 \\
\hline 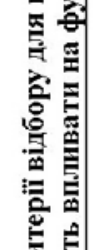 & 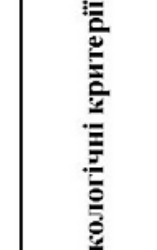 & 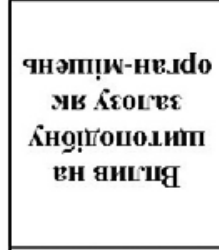 & 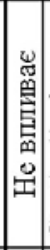 & 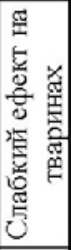 & 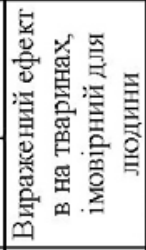 & 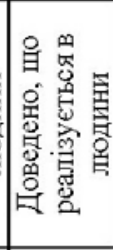 & 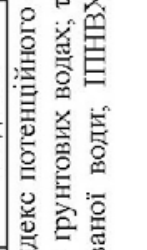 \\
\hline 约 & है & 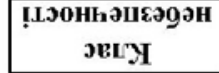 & $\nabla \mid$ & $m$ & $\mathrm{~N}$ & 一 & $\bar{\vartheta} . \hat{g}$ \\
\hline$\exists$ & & 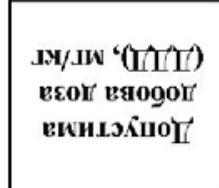 & $\left|\begin{array}{l}0 \\
0 \\
0 \\
\wedge\end{array}\right|$ & $\begin{array}{l}0 \\
8 \\
0 \\
\frac{1}{8} \\
8 \\
0\end{array}$ & $\begin{array}{l}2 \\
8 \\
8 \\
\frac{1}{8} \\
8 \\
0\end{array}$ & $\begin{array}{l}\mathscr{S} \\
\delta \\
0 \\
\text { VI }\end{array}$ & 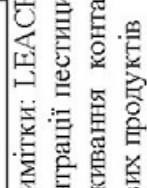 \\
\hline & $\begin{array}{l}\text { вчинєвуоц } \\
\text { онжәгеє } \mathrm{x}\end{array}$ & 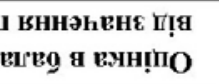 & -1 & $N$ & $m$ & $\nabla$ & 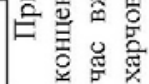 \\
\hline
\end{tabular}


Після додавання всіх отриманих балів необхідність проведення моніторингу оцінюють таким чином: при загальній сумі 11-16 балів проводити моніторинг необов'язково; 17-27 балів - моніторинг проводити бажано; 28-38 - моніторинг проводити обов'язково; 39-44 використання сполуки (препарату на їі основі) необхідно заборонити.

Слід зазначити, що проведення гігієнічного моніторингу пестицидів й агрохімікатів, що можуть впливати на функціонування щитоподібної залози, потребують в першу чергу області з інтенсивним агропромисловим виробництвом. Однак в інших областях проведення такого моніторингу є бажаним, оскільки хімічні засоби захисту рослин активно впроваджуються в сільськогосподарське виробництво світу, в тому числі в приватні підсобні господарства, які практично не контролюються, що ускладнює визначення обсягів застосування в них пестицидів.

Відбір сполук і проведення моніторингу рекомендовано здійснювати в декілька етапів.

На першому етапі потрібно провести територіальний відбір (по можливості) й вибір сполук для моніторингу. Для вибору території необхідно оцінити обсяги застосування (виробництва) хімічних сполук, що впливають на функціонування щитоподібної залози й рівні загальної та первинної захворюваності на хвороби щитоподібної залози. Під час відбору сполуки необхідно оцінити запропоновані в таблиці 1 критерії.

Власне оцінювання повинно включати моніторинг як хімічних сполук в об'єктах довкілля, так і рівнів захворюваності населення на хвороби щитоподібної залози.

Наступним етапом ми пропонуємо обов'язково проводити оцінювання ризику й прогнозування небезпечного впливу пестицидів на організм людини. Оцінювання потрібно проводити у двох аспектах: для професійних контингентів (оцінити комбінований комплексний ризик у разі застосування пестицидів, коефіцієнт можливості інгаляційного отруєння, коефіцієнт вибірковості дії) та для непрофесійних контингентів (оцінка реального ризику у випадку потрапляння в організм пестицидів).

Завершальним етапом, звісно, є створення рекомендацій щодо профілактики негативного впливу сполук, які підлягали моніторинговим дослідженням. Залежно від отриманих результатів можливе обмеження й заборона застосування речовини/препаратів на іï основі; корекція нормативів і регламентів безпечного застосування. Незалежно від отриманих результатів, але 3 корекцією програми відповідно до них, необхідно провести навчання й санітарнопросвітницьку роботу серед професійних i непрофесійних контингентів. 


\section{2. Гігієнічне обгрунтування необхідності моніторингу фунгіцидів, враховуючи їхній можливий вплив на здоров'я населення, в тому числі на щитоподібну залозу}

Сполуки, які можуть впливати на функціонування щитоподібної залози, наявні в усіх класах пестицидів: гербіцидах, фунгіцидах й інсектицидах. Ці речовини мають різні механізми дії та рівні впливу на залозу.

Найбільша кількість речовин $з$ вивченим і доведеним механізмом впливу на щитоподібну залозу - серед гербіцидів і фунгіцидів.

Найбільш вивчені й тривало застосовувані - гербіциди інгібітори 4гідроксифенілпіруватдіоксигенази (4-ГФПД). До цього класу гербіцидів належать 12 сполук, які представляють 4 хімічні класи: бензоїлциклогександіони або трикетони, бензоїлпіразоли, оксазоли та біциклооктенони ${ }^{23}$. Однак доведено, що реалізація їхнього ефекту можлива на тваринах, але практично не відбувається в людей за рекомендованих нормах витрат і режимах застосування препаратів на їхній основі.

Менш вивчені фунгіциди-піразолкарбоксаміди (інгібітори сукцинатдегідрогенази за механізмом діï), до яких належать 8 сполук: флуксапіроксад, пентіопірад, ізопіразам, седаксан, пенфлуфен, фураметпір, біксафен, бензовіндифлупір ${ }^{24}$.

На сьогодні інсектицидні формуляції на основі діючих речовин, що можуть впливати на щитоподібну залозу, тільки почали з'являтися на міжнародному ринку. Це новий хімічний клас похідних тетрамової й тетронової кислот - спіромезіфен, спіродиклофен і спіротетрамат, які поєднують у собі два механізми дії: індукцію мікросомальних ферментів печінки та пригнічення 4-гідроксифенілпіруватдіоксигенази ${ }^{25}$. Хоча обидва ефекти менш виражені, ніж у відповідних фунгіцидів і гербіцидів.

Фунгіциди-піразолкарбоксаміди - одні 3 найбільш популярних i перспективних представників свого класу, але не єдині, що можуть негативно впливати на функціонування щитоподібної залози. Аналогічний, можливо менш виражений або менш вивчений, ефект виявлено і в тріазолів, стробілуринів тощо. Ризик негативного впливу фунгіцидних препаратів на організм людини більший, як порівняти 3 інсектицидами й гербіцидами, що пов'язано 3 особливостями (по вегетації тощо) їхнього застосування й видами сільськогосподарських культур (овочі, фрукти).

\footnotetext{
${ }^{23}$ World of Herbicides Poster: HRAC Herbicide Resistance Action Committee. URL: http://www.hracglobal.com.

${ }^{24}$ Mode of action of fungicides: FRAC classification on mode of action 2014. URL: http://www.frac.info/.

${ }^{25}$ Mode of action of incecticide. IRAC classification on mode of action 2014. URL: http://www.irac.info.
} 
Враховуючи вищевикладене, саме фунгіциди ми обрали для апробації нашої методики відбору хімічних речовин для проведення моніторингових досліджень.

Для обгрунтування необхідності проведення моніторингових досліджень ми використали запропоновану в попередньому розділі бальну систему врахування комплексу показників: токсикологічних, фізико-хімічних, параметрів стійкості в об'єктах довкілля й показників ризику небезпечного впливу на населення в разі споживання контамінованих пестицидами води й харчових продуктів.

Аналіз параметрів токсикометрії показав, що більшість досліджуваних фунгіцидів є небезпечними, за винятком сполук класу анілідів (беналаксилу-М та боскаліду). За величиною допустимої добової дози (ДДД) більшість сполук є помірно небезпечними, а дифеноконазол, пенконазол, манкоцеб, беналаксил-М, валіфенал $\epsilon$ небезпечними сполуками. Для обрахування балів для цього критерію обрали величину допустимої добової дози, затвердженої в Україні, виходячи з принципів агравації. За даними ${ }^{26}$ та інших авторів у $62 \%$ випадків величини ДДД, встановлені в Україні, більш жорсткі (менші значення), як порівняти з аналогічними гігієнічними регламентами ВООЗ й ЕРА; у $30 \%$ випадків вони на одному рівні. Хоча останніми роками українські нормативи всі більше наближаються до європейських величин, що пояснюється активними процесами імплементації європейського законодавства та його гармонізації з вітчизняними нормативними документами.

Основною відмінністю в цьому випадку є можливість введення більшої кількості коефіцієнтів запасу для європейських нормативів. Для екстраполяції на людину результатів токсикологічних досліджень, проведених на тваринах, по всьому світі використовують коефіцієнт запасу, який враховує міжвидові розбіжності в чутливості (10), індивідуальну резистентність (10) і ймовірність віддалених наслідків дії (від 2 до 10), залежно від вираженості змін в організмі піддослідних тварин у вищезазначених дослідах. Свропейські експерти використовують додатково ще такі варіанти коефіцієнтів запасу: 10 або менше - за наявності лише короткочасних експериментів; 10 - за неповноти бази даних; 10 - якщо використовується не NOAEL (no adverse effect level), a LOAEL (lowest observed effect level) та ін.

Аналіз впливу досліджуваних груп фунгіцидів на щитоподібну залозу й оцінка вираженості тирозинемії, індукованої пестицидом, показав відсутність доведених наукових даних щодо цього ефекту.

${ }^{26}$ Проданчук Н. Г., Спыну Е. И. Алгоритмы оценки опасности пестицидов (классификация и управление). Современные проблемы токсикологии. 2009. № 3-4. C. 21-24. 
Однак в 1 бал за шкалою закладено можливість такого ефекту за інших умов експозиції.

Для оцінювання групи показників стійкості в навколишньому середовищі брали середні показники для грунтово-кліматичних умов центральної та південної Свропи як найбільш сільськогосподарських регіонів (на прикладі умов України).

Дослідження стійкості пестицидів у різних об'єктах навколишнього середовища показало, що найбільш стійкими в грунті були фунгіциди класу тріазолів. За критерієм «стійкість у вегетуючих сільськогосподарських культурах» фунгіциди класу тріазолів й анілідів $є$ стійкими; стробілурини, етилен-біс-дитіокарбамати, ціанопірроли, анілінопіримідини - помірно стійкі. Аналіз стабільності фунгіцидів у воді свідчить про високу стійкість тебуконазолу, беналаксилу-М у воді; ципродиніл, піриметаніл є стійкими сполуками у воді; решта фунгіцидів - помірно або нестійкі сполуки у водній фазі.

Аналіз небезпеки забруднення грунтових вод в обраних для дослідження грунтово-кліматичних умовах, а також ризику для населення від споживання контамінованої досліджуваними фунгіцидами води показали, що його величини низькі, а максимально можливі концентрації всіх досліджуваних хімічних речовин у грунтових водах незначні й набагато нижчі за допустимі.

Оцінювання ризику в разі вживання сільськогосподарської сировини, контамінованої пестицидами, показало, що в більшості випадків аналізовані фунгіциди є помірно небезпечними; тебуконазол, дифеноконазол, манкоцеб, беналаксил-М, валіфенал $\epsilon$ небезпечними сполуками.

Кожен критерій було оцінено за шкалою в балах і пораховано їхню суму (табл. 2, 3, 4).

Таблиця 2

Відбір досліджуваних фунгіцидів для проведення гігієнічного моніторингу

\begin{tabular}{|l|c|c|c|}
\hline \multirow{2}{*}{ Критерії } & \multicolumn{3}{|c|}{ Значення показника (оцінка в балах) } \\
\cline { 2 - 4 } & \multicolumn{3}{|c|}{ тріазоли } \\
\cline { 2 - 4 } & \multicolumn{1}{|c|}{ дифеноконазол } & тебуконазол & пенконазол \\
\hline $\begin{array}{l}\text { Допустима добова } \\
\text { доза (ДДД), мг/кг }\end{array}$ & 2 & 3 & 4 \\
\hline Клас небезпечності & 2 (3) & 2 (3) & 2 (3) \\
\hline $\begin{array}{l}\text { Вплив на щитоподібну } \\
\text { залозу як орган-мішень }\end{array}$ & не впливає (1) & не впливає (1) & не впливає (1) \\
\hline $\begin{array}{l}\text { Рівень тирозину в } \\
\text { плазмі крові, нмоль/мл }\end{array}$ & $<300$ (1) & $<300$ (1) & $<300$ (1) \\
\hline
\end{tabular}


Закінчення таблиці 2

\begin{tabular}{|c|c|c|c|}
\hline 1 & 2 & 3 & 4 \\
\hline $\begin{array}{l}\text { Період напівруйнуван- } \\
\text { ня }\left(\tau_{50}\right) \text { в грунті, доба } \\
\end{array}$ & 31,3 (3) & 31,3 (3) & 31,6 (3) \\
\hline $\begin{array}{l}\text { Період напівруйну- } \\
\text { вання }\left(\tau_{50}\right) \text { у воді, доба }\end{array}$ & $3,0(1)$ & $42,6(4)$ & $2,0(1)$ \\
\hline $\begin{array}{l}\text { Період напівруйнуван- } \\
\text { ня }\left(\tau_{50}\right) \text { в рослинах, доба }\end{array}$ & $9,6(2)$ & 15,5 (3) & 17,5 (3) \\
\hline $\begin{array}{l}\text { Індекс потенційного } \\
\text { забруднення грунто- } \\
\text { вих та поверхневих } \\
\text { вод (LEACH), у. о. }\end{array}$ & $1,249 \times 10^{-1}(3)$ & $\begin{array}{c}1,3441 \times 10^{+0} \\
(4)\end{array}$ & $\begin{array}{c}1,0462 \times 10^{+0} \\
\text { (4) }\end{array}$ \\
\hline $\begin{array}{l}\text { Скринінг максималь- } \\
\text { ної концентрації пес- } \\
\text { тицидів у грунтових } \\
\text { водах (SCI-GROW), } \\
\text { мкг/л } \\
\end{array}$ & $1,00 \times 10^{-2}(2)$ & $1,89 \times 10^{-2}(3)$ & $3,41 \times 10^{-3}(1)$ \\
\hline $\begin{array}{l}\text { Інтегральний показник } \\
\text { небезпечності в разі } \\
\text { вживання води } \\
\text { (ІПНВ), бали }\end{array}$ & $6(2)$ & $9(4)$ & $6(2)$ \\
\hline $\begin{array}{l}\text { Інтегральний показник } \\
\text { небезпечності за вжи- } \\
\text { вання продуктів } \\
\text { (ІПНВП), бали }\end{array}$ & $10(4)$ & $9(4)$ & $8(2)$ \\
\hline Сума балів & 26 & 31 & 23 \\
\hline
\end{tabular}

Відбір досліджуваних фунгіщидів

Таблиці 3

для проведення гігієнічного моніторингу

\begin{tabular}{|c|c|c|c|c|c|}
\hline \multirow{3}{*}{ Критерії } & \multicolumn{5}{|c|}{ Значення показника (оцінка в балах) } \\
\hline & \multicolumn{3}{|c|}{ стробілурини } & \multicolumn{2}{|c|}{ дитіокарбамати } \\
\hline & $\begin{array}{c}\text { трифлокси- } \\
\text { стробін }\end{array}$ & $\begin{array}{r}\text { піракло- } \\
\text { стробін }\end{array}$ & \begin{tabular}{|l} 
азокси- \\
стробін
\end{tabular} & метирам & манкоцеб \\
\hline 1 & 2 & 3 & 4 & 5 & 6 \\
\hline $\begin{array}{l}\text { Допустима добова } \\
\text { доза (ДДД), мг/кг }\end{array}$ & $0,02(2)$ & $0,03(1)$ & $0,03(1)$ & $0,02(2)$ & $0,005(3)$ \\
\hline Клас небезпечності & $2(3)$ & $2(3)$ & $2(3)$ & $2(3)$ & $2(3)$ \\
\hline $\begin{array}{l}\text { Вплив на щитопо- } \\
\text { дібну залозу як } \\
\text { орган-мішень }\end{array}$ & $\begin{array}{c}\text { не впливає } \\
\text { (1) }\end{array}$ & $\begin{array}{c}\text { не } \\
\text { впливає } \\
\text { (1) }\end{array}$ & $\begin{array}{c}\text { не } \\
\text { впливає } \\
(1) \\
\end{array}$ & \begin{tabular}{|c} 
не \\
впливає \\
$(1)$
\end{tabular} & $\begin{array}{c}\text { не } \\
\text { впливає } \\
(1) \\
\end{array}$ \\
\hline
\end{tabular}


Закінчення таблиці 3

\begin{tabular}{|c|c|c|c|c|c|}
\hline 1 & 2 & 3 & 4 & 5 & 6 \\
\hline $\begin{array}{l}\text { Рівень тирозину в } \\
\text { плазмі крові, } \\
\text { нмоль/мл } \\
\end{array}$ & $<300(1)$ & $<300(1)$ & $\begin{array}{c}<300 \\
(1)\end{array}$ & $<300(1)$ & $<300(1)$ \\
\hline \begin{tabular}{|l} 
Період \\
напівруйнування \\
$\left(\tau_{50}\right)$ в грунті, доба \\
\end{tabular} & 13,8 (2) & 10,7 (1) & 10,5 (1) & $7,1(1)$ & $7,5(1)$ \\
\hline $\begin{array}{l}\text { Період } \\
\text { напівруйнування } \\
\left(\tau_{50}\right) \text { у воді, доба }\end{array}$ & $1,1(1)$ & $2(1)$ & 6,1 (2) & $0,2(1)$ & $0,7(1)$ \\
\hline $\begin{array}{l}\text { Період } \\
\text { напівруйнування } \\
\left(\tau_{50}\right) \text { в рослинах, } \\
\text { доба } \\
\end{array}$ & 7,9 (3) & 8,4 (3) & $5,4(3)$ & 6,7 (3) & $6,8(3)$ \\
\hline \begin{tabular}{|l} 
Індекс \\
потенційного \\
забруднення \\
грунтових і \\
поверхневих вод \\
(LEACH), у. о.
\end{tabular} & $\begin{array}{c}3,500 \times 10^{-3} \\
\text { (1) }\end{array}$ & $\begin{array}{c}2,200 \times \\
\times 10^{-3}(1)\end{array}$ & $\begin{array}{c}1,194 \times \\
\times 10^{-1} \\
(3)\end{array}$ & $\begin{array}{c}1,420 \times \\
\times 10^{-2}(1)\end{array}$ & $\begin{array}{c}1,000 \times \\
\times 10^{-4}(1)\end{array}$ \\
\hline \begin{tabular}{|l} 
Скринінг \\
максимальної \\
концентрації \\
пестицидів у \\
грунтових водах \\
(SCI-GROW), \\
мкг/л
\end{tabular} & $\begin{array}{c}2,30 \times 10^{-3} \\
(2)\end{array}$ & $\begin{array}{c}1,78 \times \\
\times 10^{-3}(2)\end{array}$ & $\begin{array}{c}1,23 \times \\
\times 10^{-2} \\
(3)\end{array}$ & $\begin{array}{c}4,74 \times \\
\times 10^{-2}(3)\end{array}$ & $\begin{array}{c}3,90 \times \\
\times 10^{-2}(3)\end{array}$ \\
\hline \begin{tabular}{|l} 
Інтегральний \\
показник \\
небезпечності в \\
разі вживання \\
води (ІПНВ), бали \\
\end{tabular} & $3(1)$ & $3(1)$ & $3(1)$ & $4(1)$ & $3(1)$ \\
\hline \begin{tabular}{|l} 
Інтегральний \\
показник \\
небезпечності в \\
разі вживання \\
продуктів \\
(ІПНВП), бали \\
\end{tabular} & $8(3)$ & 7 (3) & 7 (3) & $8(3)$ & $9(4)$ \\
\hline Сума балів & 20 & 18 & 22 & 20 & 22 \\
\hline
\end{tabular}


Таблиця 4

Відбір досліджуваних фунгіцидів для проведення гігіснічного моніторингу

\begin{tabular}{|c|c|c|c|c|c|}
\hline \multirow{3}{*}{ Критерії } & \multicolumn{5}{|c|}{ Значення показника (оцінка в балах) } \\
\hline & \multicolumn{2}{|c|}{ аніліди } & \multicolumn{3}{|c|}{ анілінопіримідини } \\
\hline & $\begin{array}{c}\text { бенал- } \\
\text { аксил-М }\end{array}$ & боскалід & $\begin{array}{l}\text { ципро- } \\
\text { диніл }\end{array}$ & $\begin{array}{c}\text { піри- } \\
\text { метаніл }\end{array}$ & $\begin{array}{c}\text { валі- } \\
\text { фенал }\end{array}$ \\
\hline 1 & 2 & 3 & 4 & 5 & 6 \\
\hline $\begin{array}{l}\text { Допустима добова } \\
\text { доза (ДДД), мг/кг }\end{array}$ & $0,005(3)$ & $0,04(1)$ & $0,03(1)$ & $0,02(2)$ & $0,005(3)$ \\
\hline $\begin{array}{l}\text { Клас } \\
\text { небезпечності }\end{array}$ & $3(2)$ & $3(2)$ & $2(3)$ & $2(3)$ & $2(3)$ \\
\hline $\begin{array}{l}\text { Вплив на щитопо- } \\
\text { дібну залозу як } \\
\text { орган-мішень }\end{array}$ & $\begin{array}{c}\text { не } \\
\text { впливає } \\
\text { (1) }\end{array}$ & $\begin{array}{c}\text { не } \\
\text { впливає } \\
\text { (1) }\end{array}$ & $\begin{array}{c}\text { не } \\
\text { впливає } \\
\text { (1) }\end{array}$ & $\begin{array}{c}\text { не } \\
\text { впливає } \\
\text { (1) }\end{array}$ & $\begin{array}{c}\text { не } \\
\text { впливає } \\
\text { (1) }\end{array}$ \\
\hline $\begin{array}{l}\text { Рівень тирозину в } \\
\text { плазмі крові, } \\
\text { нмоль/мл }\end{array}$ & $<300(1)$ & $<300(1)$ & $\begin{array}{l}<300 \\
\quad(1)\end{array}$ & $\begin{array}{c}<300 \\
(1)\end{array}$ & $<300(1)$ \\
\hline $\begin{array}{l}\text { Період } \\
\text { напівруйнування } \\
\left(\tau_{50}\right) \text { в грунті, доба }\end{array}$ & $10,6(1)$ & $13,8(2)$ & $12,3(2)$ & $11,0(2)$ & $7,8(1)$ \\
\hline $\begin{array}{l}\text { Період } \\
\text { напівруйнування } \\
\left(\tau_{50}\right) \text { у воді, доба }\end{array}$ & $38(4)$ & $9,0(2)$ & $12,5(3)$ & $16,5(3)$ & $5(2)$ \\
\hline $\begin{array}{l}\text { Період } \\
\text { напівруйнування } \\
\left(\tau_{50}\right) \text { в рослинах, } \\
\text { доба }\end{array}$ & $14,3(3)$ & $17,8(3)$ & $8,2(2)$ & $7,7(2)$ & $7,3(2)$ \\
\hline $\begin{array}{l}\text { Індекс } \\
\text { потенційного } \\
\text { забруднення } \\
\text { грунтових і } \\
\text { поверхневих вод } \\
\text { (LEACH), у. о. }\end{array}$ & $\begin{array}{c}4,880 \times \\
\times 10^{-2}(1)\end{array}$ & $\begin{array}{c}8,220 \times \\
\times 10^{-2}(1)\end{array}$ & $\begin{array}{c}7,020 \times \\
\times 10^{-2} \\
(1)\end{array}$ & $\begin{array}{c}4,400 \times \\
\times 10^{-3} \\
(1)\end{array}$ & $\begin{array}{r}1,115 \times \\
\times 10^{-1}(1)\end{array}$ \\
\hline $\begin{array}{l}\text { Скринінг } \\
\text { максимальної } \\
\text { концентрації } \\
\text { пестицидів у } \\
\text { грунтових водах } \\
\text { (SCI-GROW), } \\
\text { мкг/л }\end{array}$ & $\begin{array}{c}2,67 \times 10^{-3} \\
(2)\end{array}$ & $\begin{array}{c}1,67 \times \\
\times 10^{-2}(3)\end{array}$ & $\begin{array}{c}9,38 \times \\
\times 10^{-3} \\
(2)\end{array}$ & $\begin{array}{c}4,33 \times \\
\times 10^{-2} \\
(3)\end{array}$ & $\begin{array}{c}2,85 \times \\
\times 10^{-3}(2)\end{array}$ \\
\hline
\end{tabular}


Закінчення таблиці 4

\begin{tabular}{|l|c|c|c|c|c|}
\hline \multicolumn{1}{|c|}{1} & 2 & 3 & 4 & 5 & 6 \\
\hline $\begin{array}{l}\text { Інтегральний } \\
\text { показник } \\
\text { небезпечності в } \\
\text { разі вживання } \\
\text { води (ІПНВ), бали }\end{array}$ & 7 (3) & $5(2)$ & $6(2)$ & $5(2)$ & $6(2)$ \\
\hline $\begin{array}{l}\text { Інтегральний } \\
\text { показник } \\
\text { небезпечності в } \\
\text { разі вживання } \\
\text { продуктів } \\
\text { (ІПНВП), бали }\end{array}$ & $9(4)$ & 7 (3) & 7 (3) & $8(3)$ & $9(4)$ \\
\hline Сума балів & $\mathbf{2 5}$ & $\mathbf{2 1}$ & $\mathbf{2 1}$ & $\mathbf{2 3}$ & $\mathbf{2 2}$ \\
\hline
\end{tabular}

Оцінювання небезпечності за бальною шкалою та підсумовування балів показало, що моніторинг фунгіцидів класу тріазолів (дифеноконазолу, пенконазолу) проводити бажано, тебуконазолу - обов'язково. Моніторингові дослідження фунгіцидів класу стробілуринів, дитіокарбаматів, анілідів й анілінопіримідинів проводити бажано.

\section{ВИСНОВКИ}

Запропоновано способи комплексного оцінювання потенційного негативного впливу на організм людини хімічних речовин у випадку вживання контамінованої води й сільськогосподарської продукції (на прикладі пестицидів). Перший спосіб грунтується на бальній оцінці інтегрального показника небезпечності у випадку споживання контамінованої пестицидами води, величину якого отримують в результаті додавання балів, що надаються основним критеріям, які характеризують небезпеку для людини в разі потрапляння хімічної речовини у воду: індексу потенційного вимивання в грунтові й поверхневі води (LEACH), періоду напівруйнування у воді й допустимій добовій дозі. Інтегральний показник небезпечності у випадку вживання харчових продуктів другим способом отримують додаванням балів, присвоєних основним критеріям, що характеризують небезпеку для людини під час вживання контамінованої хімічними речовинами продукції: допустимій добовій дозі, періоду напівруйнування в рослинах і середньодобовому споживанню продукту.

Проведений аналіз токсичності, механізмів дії, ризику для навколишнього середовища й організму людини пестицидів, що можуть впливати на щитоподібну залозу, дав змогу вдосконалити методику проведення моніторингу небезпечних хімічних речовин, які 
можуть впливати на функціонування щитоподібної залози (на прикладі фунгіцидів). Було обгрунтовано специфічні токсикологічні критерії (вплив на щитоподібну залозу й рівень тирозинемії), додаткові критерії оцінки небезпечності для навколишнього середовища (індекс потенційного вимивання в грунтові й поверхневі води (LEACH) i скринінг максимальної концентрації пестицидів у грунтових водах $(\mathrm{SCI}-\mathrm{GROW}))$ й організму людини (інтегральний показник небезпечності в разі вживання контамінованої води (IПНВВ) й інтегральний показник небезпечності за вживання контамінованих харчових продуктів (ІПНВХП)) та бальну оцінку критеріїв вибору сполук-тиреотоксикантів для цілей моніторингу.

Виходячи 3 отриманих результатів апробації запропонованої методики на фунгіцидах більшість досліджуваних сполук віднесено до другої групи пестицидів, гігієнічний моніторинг яких бажаний, але не обов'язковий. Це пов'язано, 3 одного боку, 3 їхньою невисокою токсичністю (досить високі значення величин допустимих добових доз, відсутність доведеного впливу на щитоподібну залозу), а з іншого, малою стійкістю в об'єктах навколишнього середовища. Виключення становив тебуконазол, моніторинг якого обов'язковий через його високу стійкість у воді та значний ризик у випадку споживання ії людиною.

\section{АНОТАЦІЯ}

Моделі моніторингу довкілля, які існують на сьогодні, не містять специфічні критерії відбору хімічних сполук, що можуть впливати на функціонування щитоподібної залози. Однак це питання $\epsilon$ надзвичайно актуальним для багатьох країн світу. Тому було обгрунтовано специфічні токсикологічні критерії (вплив на щитоподібну залозу й рівень тирозинемії), додаткові критерії оцінювання небезпечності для навколишнього середовища (індекс потенційного вимивання в грунтові й поверхневі води та скринінг максимальної концентрації пестицидів в грунтових водах) й організму людини (інтегральний показник небезпечності в разі вживання контамінованої води й інтегральний показник небезпечності за вживання контамінованих харчових продуктів). Запропоновано бальну оцінку критеріїв вибору сполуктиреотоксикантів для моніторингу. Методику апробовано на найбільш широко використовуваних фунгіцидах і встановлено, що моніторинг фунгіцидів класу тріазолів (дифеноконазолу, пенконазолу), стробілуринів, дитіокарбаматів, анілідів і анілінопіримідинів проводити бажано, тріазолу тебуконазолу - обов'язково. 


\section{ЛITЕРАТУРА}

1. Pradyot Patnaik. Handbook of Environmental Analysis: Chemical Pollutants in Air, Water, Soil, and Solid Wastes, Third Edition. New York : Tailor and Francis Group, 2018. 628 p.

2. EPA Monitoring Programs. URL: https://www.epa.gov/measurementsmodeling/monitoring-programs.

3. UNECE AND UNFPA. "UNECE monitoring framework for the icpd programme of action beyond 2014”. Geneva and Istanbul : UNECE and UNFPA, 2018.

4. Fifth Ministerial Conference "Environment for Europe". URL: http://www.unece.org/fileadmin//DAM/env/efe/Kiev/proceedings/welcome. html.

5. Acute occupational pesticide-related illness and injury / G.M. Calvert et al. United States, 2007-2011. The National Institute for Occupational Safety and Health (NIOSH). URL: https://www2a.cdc.gov/nioshtic-2/ BuildQyr.asp.

6. Occupational exposure to pesticides and the incidence of lung cancer in the agricultural health study. The National Institute for Occupational Safety and Health (NIOSH) / M.R. Bonneret al. URL: https://www2a.cdc.gov/nioshtic-2/BuildQyr.as.

7. State of the Scientific of Endocrine Disrupting chemicals - 2012. URL: http://www.who.int/ceh/publications/endocrine/en/.

8. Вавріневич О. П. Гігієнічне обгрунтування критеріїв відбору для проведення моніторингу в агропромисловому комплексі України. Довкілля і здоров'я. 2019. № 1. C. 4-9. doi.org/10.32402/dovkil2019.01.004.

9. Mechanism of action of 4-hydroxyphenylpyruvate dioxygenase inhibitor herbicide on homoterm animals and humans / A. M. Antonenko et al. Journal of Pre-Clinical and Clinical Research. 2015. Vol. 9. № 2. P. 148-153. DOI: https://doi.org/10.5604/18982395.1186496.

10. Антоненко А.М., Коршун М.М., Мілохов Д.С. Особливості механізму дії інгібіторів сукцинатдегідрогенази на організм теплокровних тварин та людини. Сучасні проблеми токсикології, харчової та хімічної безпеки. 2015. № 4(72). С. 23-29.

11. Prediction of soil and ground water contamination with fungicides of different classes according to soil and climate conditions in Ukraine and other European countries / O.P. Vavrinevych et al. Georgian Medical News. 2015. № 5(242). C. 73-84.

12. Comparative hygienic risk assessment of groundwater contamination by herbicides of different chemical classes and hazard prediction for human after consumption of contaminated water / A.M. Antonenko et al. Journal of Education, Health and Sport. Poland. 2016. № 9. P. 873-882. DOI: http://dx.doi.org/10.5281/zenodo.161844. 
13. Claudia A. Spadotto Screening method for assessing pesticide leaching potential. Pesticidas : R. Ecotoxicol. Curitiba. 2002. Vol. 12. P. 69-78.

14. European Food Safety Authority. Exposure to pesticides data for residents and bystanders, and for environmental risk assessment. URL: https://data.europa.eu/euodp/data/dataset/exposure-to-pesticides-data-forresidents-and-bystanders-and-for-environmental-risk-assessment.

15. GUIDANCE OF EFSA: Guidance on the assessment of exposure of operators, workers, residents and bystanders in risk assessment for plant protection products. European Food Safety Authority (EFSA) Journal. 2014. № 12(10). P. 3874-3924.

16. Report of the Joint working group on bystander risk assessment (BRAWG). Advisory Committee on Pesticides Committee on Toxicity of Chemicals in Food, Consumer Products and the Environment, US EPA. 2013. $70 \mathrm{p}$.

17. Prediction of pesticide risks to human health by drinking water extracted from underground sources / A.M. Antonenko et al. Georgian Medical News. 2015. № 7-8(244-245). P. 99-106.

18. Спосіб прогнозування негативного впливу на здоров'я населення пестицидів при їх потраплянні в організм 3 водою : пат. на корисну модель № 105428; заявл. 03.07.2015; опубл. 25.03.2016, Бюл. № 6.4 с.

19. Гігієнічне обгрунтування моделі прогнозування небезпеки для людини при вживанні сільськогосподарських продуктів контамінованих пестицидами (на прикладі фунгіцидів класу піразолкарбоксамідів) / А.М. Антоненко та ін. The unity of science. Vienna, Austria. August, 2018. P. 46-48.

20. WHO child growth standards : length/height-for-age, weight-for-age, weight-for-length, weight-forheight and body mass index-for-age: methods and development. World Health Organization. France. 2006. 336 p.

21. Гігієнічне обгрунтування моделі прогнозування небезпеки для людини при вживанні сільськогосподарських продуктів контамінованих пестицидами (на прикладі фунгіцидів класу піразолкарбоксамідів). Інформаційний лист на нововведення у сфері охорони здоров'я. Міністерство охорони здоров'я України, Український центр наукової медичної інформації та патентно-ліцензійної роботи. Вип. 1 «Гігієна харчування». 2018. № 28.5 c.

22. Improvement of the monitoring system in the environment of pesticides affecting thyroid gland / A.M. Antonenko et al. Довкілля $i$ здоров'я. 2019. № 4(93). С. 12-18.

23. World of Herbicides Poster: HRAC Herbicide Resistance Action Committee. URL: http://www.hracglobal.com (дата звертання 25.05.2020).

24. Mode of action of fungicides: FRAC classification on mode of action 2014. URL: http://www.frac.info/. 
25. Mode of action of incecticide. IRAC classification on mode of action 2014. URL: http://www.irac.info.

26. Проданчук Н.Г., Спыну Е И. Алгоритмы оценки опасности пестицидов (классификация и управление). Современные проблемь токсикологии. 2009. № 3-4. С. 21-24.

\section{Information about authors:}

Antonenko A. M.,

Doctor of Medicine, Professor of Hygiene and Ecology Department № 1 Bogomolets National Medical University 13, Shevchenka blvd, Kyiv, 01004, Ukraine Vavrinevych O. P., Doctor of Medicine, Professor of Hygiene and Ecology Department № 1 Bogomolets National Medical University 13, Shevchenka blvd, Kyiv, 01004, Ukraine 